\title{
Synthesis of $\mathrm{Zn}$ compounds derived from $1 H$-benzimidazol-2-ylmethanamine
}

\author{
Antonio R. Tapia-Benavides, ${ }^{\text {a }}$ Margarita Tlahuextl, ${ }^{\text {a,* Hugo Tlahuext, }}{ }^{\text {b }}$ \\ and Carlos Galán-Vidal ${ }^{\mathrm{a}}$ \\ ${ }^{a}$ Centro de Investigaciones Químicas, Universidad A. del Estado de Hidalgo, Carretera \\ Pachuca-Tulancingo Km 4.5. U. Universitaria. CP 42184 Mineral de la Reforma, Hidalgo, \\ México \\ ${ }^{b}$ Centro de Investigaciones Químicas, Universidad A. del Estado de Morelos, Av. Universidad \\ 1001 Col., Chamilpa, CP 62100, Cuernavaca Morelos, México \\ E-mail: tromero@uaeh.edu.mx
}

Dedicated to Professor Rosalinda Contreras on the occasion of her $60^{\text {th }}$ anniversary

\begin{abstract}
The influence of the $\mathrm{pH}$ on the synthesis of $\mathrm{Zn}$ (II) complexes derived from $1 H$-benzimidazol-2ylmethanamine (HL) has been investigated with X-ray crystallography, FAB mass spectrometry, NMR, infrared and Raman spectroscopy. The crystal structures of (1H-benzimidazol-2ylmethanamine)tetrachlorozincate(2-) dihydrogen $\left[\mathrm{H}_{3} \mathrm{LZnCl}_{4}\right] \quad$ (2), (1H-benzimidazol-2ylmethanamine- $\kappa \mathrm{N}^{3}$ )trichlorozincate (1-) hydrogen hydrate $\quad\left[\mathrm{H}_{2} \mathrm{LZnCl}_{3}\right] \cdot \mathrm{H}_{2} \mathrm{O} \quad$ (3), (1Hbenzimidazol-2-ylmethanamine- $\kappa^{2} \mathrm{~N}^{2}, \mathrm{~N}^{3}$ )dichlorozinc(II) $\quad\left[\mathrm{HLZnCl}_{2}\right] \quad$ (4) and $\operatorname{Bis}[1 H$ benzimidazol-2-ylmethanamine- $\left.\mathrm{k}^{2} \mathrm{~N}^{2}, \mathrm{~N}^{3}\right]$ chlorozinc(II) chloride hydrate $\left[(\mathrm{HL})_{2} \mathrm{ZnCl}\right] \mathrm{Cl} \cdot \mathrm{H}_{2} \mathrm{O}(\mathbf{5})$ are reported. Compounds 2-4 exhibit a distorted tetrahedral environment around the metal center. Complex 5 has distorted trigonal bipyramidal geometry. The crystalline structures of 2-5 show the presence of strong intermolecular hydrogen bond interactions that produces graph sets with pseudo-macrocyclic network. The NMR studies show the dynamic behavior of compounds 3-5 due to break-formation phenomena of $\mathrm{N} \rightarrow$ Zn bonds.
\end{abstract}

Keywords: Benzimidazole, zinc, X-ray, Raman, infrared, NMR

\section{Introduction}

The $\mathrm{Zn}(\mathrm{II})$ has a relevant role in chemical and biological systems. ${ }^{1-5}$ For example, in the active site of zinc-metalloenzymes there is present a $\mathrm{Zn}$ (II) ion coordinated principally to histidine, cysteine, aspartic acid, or $\mathrm{H}_{2} \mathrm{O}{ }^{4,6-8}$ The interaction of $\mathrm{Zn}(\mathrm{II})$ ion with the environment of the 
active site has a significant impact on the catalytic activity of these enzymes. ${ }^{4,6-8}$ Normally, the $\mathrm{Zn}$ (II) ion has a tetrahedral geometry in the active site, however, the coordination and geometry of this ion depend on the acid-base properties of the histidine residues. ${ }^{4,6,9}$ The presence of imidazolic-histidine residues, that can donate or accept various protons, allows different types of $\mathrm{Zn}$ coordination in the active site. Thus, the activity of the zinc-metalloenzymes has a delicate and sensitive dependence of $\mathrm{pH}$ values. ${ }^{6}$

Polyligand derived from imidazole and benzimidazole are used as working models to understanding the role of the $\mathrm{Zn}$ (II) ions in biological systems because they can mimic the histidine side chain. ${ }^{4,7-9}$ In our ongoing research on benzimidazole derivatives we are interested in the coordinating acid and behavior of $1 H$-benzimidazol-2-ylmethanamine (HL) $\mathbf{1}^{10-13}$ Compound 1 has three pKa values (Scheme 1); at pH below 2.9 the three nitrogen atoms are blocked by protons $\left(\mathrm{H}_{3} \mathrm{~L}^{2+}\right)$ and apparently this benzimidazole could not coordinate to $\mathrm{Zn}$ (II). ${ }^{11}$ When the $\mathrm{pH}$ values increase $\mathbf{1}$ could act as a mono- or bidentate ligand. In any of three cases, the coordinated form of the metallic ion will be different. On the other hand, it is known that $\mathrm{Zn}(\mathrm{II})$ is selective for coordination of chloride ions because they are small and hydrophilic species. ${ }^{14,15}$ In the presence of $\mathrm{Cl}^{-}$ions the formation of $\mathrm{Zn}$ (II) complexes is favored because of the existence of intermolecular hydrogen bonds. ${ }^{14}$ In this paper we studied the synthesis of four complexes at different $\mathrm{pH}$, concentration and reaction times in order to analyze the factors that determine the coordination of $\mathrm{Zn}$ (II) ions to $1 H$-benzimidazol-2-ylmethanamine. These compounds were also characterized using NMR, X-ray crystallography, infrared and Raman spectroscopies.

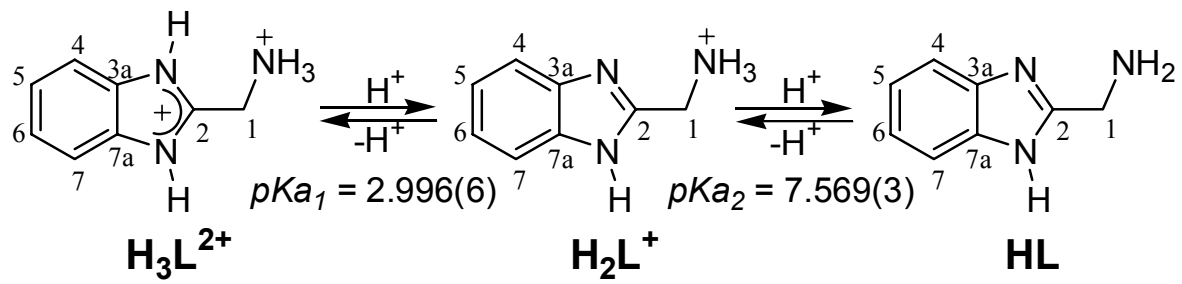

Scheme 1. Acid-base behavior of $1 H$-benzimidazol-2-ylmethanamine 1. ${ }^{11}$

\section{Results and Discussion}

In aqueous solution, $\mathrm{Zn}$ (II) presents a set of chemical equilibria that basically depend on the ion concentration and $\mathrm{pH}$. The predominance-existence diagrams show that $\mathrm{Zn}(\mathrm{II})$ species can only occur in acid solutions. ${ }^{16,17}$ In basic solutions, insoluble $\mathrm{Zn}(\mathrm{OH})_{2}$ is formed and this limits the reactivity of $\mathrm{Zn}(\mathrm{II})$. However, it is possible to reduce the formation of insoluble hydroxycompounds through the addition of liganting agents. ${ }^{16}$ The presence of the chloride ion (for which $\mathrm{Zn}$ (II) has great affinity ${ }^{14}$ ) in the reaction environment is specially important because it allows the formation of soluble chemical species $\left(\mathrm{ZnCl}^{+}, \mathrm{ZnCl}_{2}, \mathrm{ZnCl}_{3}^{-}\right)$able to react with 
polydentate ligands. Thus, we performed the treatment of 1 with $\mathrm{Zn}$ (II) in aqueous media and effected scanning reactions by two means: 1$)$ At constant concentration $(0.1 \mathrm{M})$, the reaction of 1 with $\mathrm{ZnCl}_{2}$ was performed at different values of $\mathrm{pH}$ (from 1 to 7); and 2) At variable concentrations (from 0.06 to $0.12 \mathrm{M}$ ), $\mathrm{H}_{3} \mathrm{~L}^{2+}$ dihydrochloride was made to interact with $3 \mathrm{Zn}(\mathrm{OH})_{2} \cdot 2 \mathrm{ZnCO}_{3}$.

\section{Reaction of 1 with $\mathrm{ZnCl}_{2}$ at variable $\mathrm{pH}$}

At constant concentration, we scanned, the reaction of 1 with $\mathrm{ZnCl}_{2}$ every 0.5 units of $\mathrm{pH}$ through the use of infrared spectroscopy and X-Ray diffraction (Figure 1). We found that the action of $\mathrm{Zn}(\mathrm{II})$ ion changes the $\mathrm{pKa}$ values of 1 . Thus, in the range of $\mathrm{pH}$ from 0 to 2.4 compound $\mathbf{2}$ is present. The ligand in $\mathbf{2}$ features the entire coordination center blocked by N-H bonds. In these reaction conditions, the $\mathrm{Zn}$ (II) ion assumes the form of tetrachlorozincate(2-). ${ }^{18}$ At $\mathrm{pH}$ 2.4, compounds $\mathbf{2}$ and $\mathbf{3}$ are present in solution, but at higher $\mathrm{pH}$ 's, $\mathbf{2}$ disappears and $\mathbf{3}$ predominates. Formation of 3 is due to the first deprotonation of $\mathbf{1}\left(\mathrm{H}_{3} \mathrm{~L}^{2+} \rightleftarrows \mathrm{H}_{2} \mathrm{~L}^{+}+\mathrm{H}^{+}\right)$and the formation of the $\mathrm{N} \rightarrow \mathrm{Zn}$ bond on the imidazolic $\mathrm{N}$ atom.
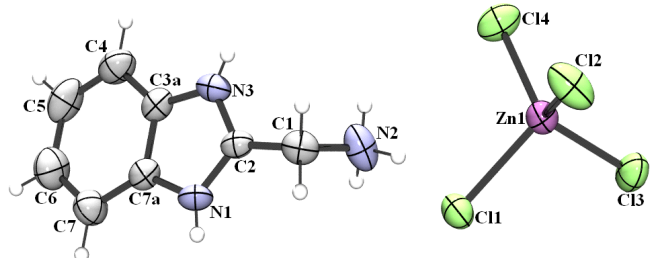

Compound 2

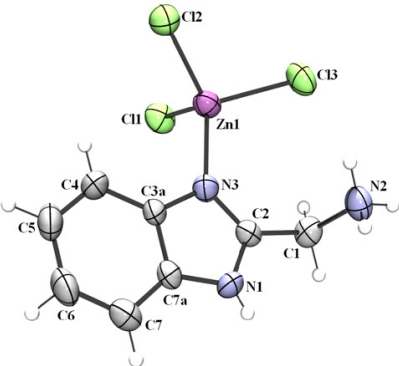

Compound 3

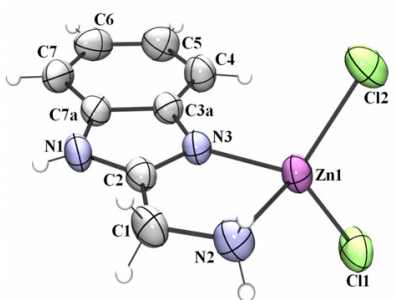

Compound 4

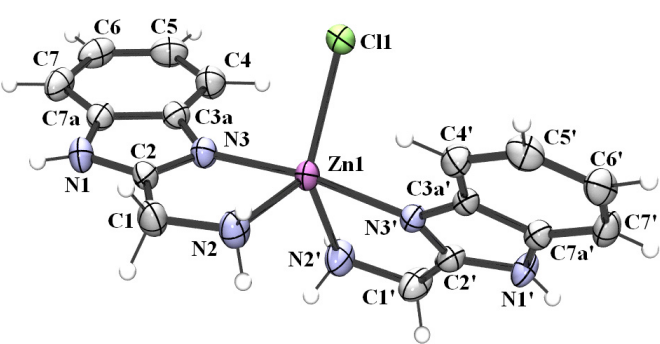

Compound 5

Figure 1. Ortep representation of compounds $\left[\mathrm{H}_{3} \mathrm{LZnCl}{ }_{4}\right] \mathbf{2} ;\left[\mathrm{H}_{2} \mathrm{LZnCl}_{3}\right] \cdot \mathrm{H}_{2} \mathrm{O} \mathbf{3} ;\left[\mathrm{HLZnCl}_{2}\right] \mathbf{4}$ and $\left[(\mathrm{HL})_{2} \mathrm{ZnCl}\right] \mathrm{Cl} \cdot \mathrm{H}_{2} \mathrm{O}$ 5, where $\mathrm{HL}$ is $1 \mathrm{H}$-benzimidazol-2-ylmethanamine.

In absence of any metallic ion, the neutral species of $\mathbf{1}\left(\mathrm{H}_{2} \mathrm{~L}^{+} \rightleftarrows \mathrm{HL}+\mathrm{H}^{+}\right)$must predominate after $\mathrm{pH} 7{ }^{11}$ However, we determine the existence of compound $\mathbf{5}$ at more acidic values of $\mathrm{pH}$ (4.5 to 6.4). The presence of the bidentate form of the ligand 1 in solution and its chelate coordination with the $\mathrm{Zn}$ (II) ion perhaps favor the formation of compound $\mathbf{5}$ in these acid 
conditions. However, total evaporation of the solutions at pH 5.6 - 6.4 leads only to compound 4. Presumably, the slow evaporation causes the increase of the chloride concentration and instead of compound $\mathbf{5}$, the complex 4 is obtained.

\section{Reaction of $\mathrm{H}_{3} \mathrm{~L}^{2+}$ with $3 \mathrm{Zn}(\mathrm{OH})_{2} \cdot 2 \mathrm{ZnCO}_{3}$ at concentration variable}

Although the $3 \mathrm{Zn}(\mathrm{OH})_{2} \cdot 2 \mathrm{ZnCO}_{3}$ salt is practically insoluble in water, the presence of $\mathbf{1}$ in the form of $\mathrm{H}_{3} \mathrm{~L}^{2+}$ makes it possible the reaction of $\mathrm{Zn}(\mathrm{II})$. A slow acid-base reaction leads to produce the neutral form of $\mathbf{1}$ (HL) and makes Zn(II) become soluble. Thus, the concentration of $\mathrm{Zn}$ (II) in solution is always small and the ligand is in excess. We effected a set of reactions of $\mathrm{H}_{3} \mathrm{~L}^{2+}$ with $3 \mathrm{Zn}(\mathrm{OH})_{2} \cdot 2 \mathrm{ZnCO}_{3}$ at different concentrations of benzimidazole (from 0.06 to 0.12 M). In all cases, when the mixture was stirred for 24 hours, compound 4 was obtained. On the other hand, when the mixture was stirred for 30 minutes, the reaction yielded instead compound 5. Moreover, we found that the best conditions of reaction (good yields and excellent quality of crystallization) were achieved at benzimidazole concentrations of $0.08 \mathrm{M}$.

\section{Infrared and Raman studies}

The infrared and Raman studies confirm the presence of the Zn-compounds 2-5. Thus, the in plane mode vibrations in benzimidazoles are present between 419 and $1620 \mathrm{~cm}^{-1} 19$ and the characteristic signal for the in-plane vibration of the imidazole $\mathrm{N}-\mathrm{H}$ is localized near $1590 \mathrm{~cm}^{-1}$. The in-plane N-H vibrations for 2 are shifted toward smaller frequencies $\left(\Delta \delta=25 \mathrm{~cm}^{-1}\right)$ compared to compounds 3-5 $\left(\delta=1588 \mathrm{~cm}^{-1}\right)$ and this makes evident the presence of strong hydrogen bond interactions. ${ }^{19}$ In contrast to complexes $2-4$, where the $\mathrm{C}=\mathrm{N}$ stretching vibration appears as a lone signal in the region of $1617-1624 \mathrm{~cm}^{-1}$, compound 5 shows two signals (1624 and $1651 \mathrm{~cm}^{-1}$ ) that support the $\mathrm{Zn}$ penta-coordination. On the other hand, IR spectra of $\mathbf{1}$ and $\mathbf{3}$ show a signal at $1598 \mathrm{~cm}^{-1}$ attributed to in-plane bending vibrations of the $\mathrm{NH}_{3}$ group, ${ }^{20}$ while the absence of this signal in compounds $\mathbf{4}$ and $\mathbf{5}$ suggests the chelate coordination of HL ligand to $\mathrm{Zn}$. Moreover, the typical $\mathrm{NH}_{2}$ wagging vibrations for compounds $\mathbf{4}$ and $\mathbf{5}$ are found at 680 and $673 \mathrm{~cm}^{-1}$, respectively, and support the chelate coordination in these compounds. ${ }^{20,21}$ The set of signals for the aromatic $\mathrm{C}-\mathrm{H}$ and imidazolic $\mathrm{N}-\mathrm{H}$ out-plane mode vibrations are characteristic for each of the $\mathrm{Zn}$ compounds 3-5 in the infrared spectra and therefore are useful to differentiate one another. Thus, for 3 the out-plane mode vibrations are grouped next to $751 \mathrm{~cm}^{-1}$ as strong, thin signals, in the case of 4-5 the corresponding signals are strong and coarse and are distributed in the region form 535 to $768 \mathrm{~cm}^{-1}$. Nevertheless, the double coordination of 1 with the $\mathrm{Zn}$ atom and its minor symmetry causes a larger number of these signals for $\mathbf{5}(546,609,640,711,756$, $\left.771 \mathrm{~cm}^{-1}\right)$ than for $4\left(533,627,758,769 \mathrm{~cm}^{-1}\right)$.

In Raman spectra the $\mathrm{Zn}-\mathrm{Cl}$ stretching vibrations for $\mathbf{2}$ and $\mathbf{3}$ are observed as single signals (286, and $284 \mathrm{~cm}^{-1}$ respectively) and are evidence that in these molecules the $\mathrm{Zn}-\mathrm{Cl}$ bonds are symmetrically equivalent. ${ }^{22}$ For compound 4 the two $\mathrm{Zn}-\mathrm{Cl}$ stretching vibrations are observed in 310 and $235 \mathrm{~cm}^{-1}$ and confirm the presence of two chlorine atoms bonded to $\mathrm{Zn}$. On the one hand, for compound 5 the $\mathrm{Zn}-\mathrm{Cl}$ stretching vibration $\left(230 \mathrm{~cm}^{-1}\right)$ appears at a lower frequency 
than in the case of 2-4. This result is in agreement with the penta-coordination of compound 5 and a longer $\mathrm{Zn}-\mathrm{Cl}$ bond distance. Furthermore, two $\mathrm{Zn}-\mathrm{N}$ stretching vibrations are observed in compounds 4 and 5 (424 and $490 \mathrm{~cm}^{-1}$ ) that make evident the chelate coordination of ligand HL in these compounds. ${ }^{23}$

\section{NMR studies in solution}

The ${ }^{13} \mathrm{C}$ NMR spectra of compounds 2-5 have a symmetric behavior and only one set of signals were found for all aromatic carbons (Table 1). Thus, in all cases C5 and C6 have the same resonance. Compared to 1 , the presence of $\mathrm{N} \rightarrow \mathrm{Zn}$ coordination bond on the imidazole nitrogen in compounds 3-4 causes a shift toward lower frequencies for C5 and C6 ( $\Delta \delta=3.7-3.1 \mathrm{ppm})$. However, in compounds 4 and 5, C4 and C7 have broad signals that are evidence of a dynamic behavior. It is known that the $\mathrm{Zn}$ complexes are characterized by a high coordinate flexibility due to presence of bond-breaking phenomena $(\mathrm{Zn} \leftarrow \mathrm{L} \rightleftarrows \mathrm{Zn}+\mathrm{L}){ }^{24-27}$ Therefore, it is probable that in aqueous solution, compounds 3-5 undergo $\mathrm{N} \rightarrow \mathrm{Zn}$ bond-breaking phenomena at aromatic nitrogen atoms (Scheme 2). On the other hand, it is known that in diazoles the interconversion between tautomers is very fast due to the employ of a third molecule. ${ }^{28-34}$ Thus, in compounds 3$\mathbf{5}$, it is possible that the free benzimidazole groups present an intermolecular proton transfer mechanism with the solvent $\left(\mathrm{D}_{2} \mathrm{O}\right)$ and this fact perhaps explains the high symmetry of their NMR spectra. When the solvent is evaporated of the NMR tubes with $\mathbf{3}$ or $\mathbf{5}$ complexes, the infrared spectra and X-ray diffraction of the solid residues show that these compounds have once more the original crystalline structure where the aromatic nitrogen atoms present the $\mathrm{N} \rightarrow \mathrm{Zn}$ coordination. This information corroborates the existence of $\mathrm{N} \rightarrow \mathrm{Zn}$ bond-breaking equilibrium of 3 and 5 in aqueous solutions. On the other hand, in ${ }^{1} \mathrm{H}$ NMR the methylene hydrogens (H1) resonances of compounds 4 and 5 are displaced toward lower frequencies $(\Delta \delta=0.54-0.2 \mathrm{ppm})$ with respect to compounds 2 and 3. This result confirms the coordination of the amine group with the $\mathrm{Zn}(\mathrm{II})$ ion in $\mathbf{4}$ and $\mathbf{5}$.

Table $1 .{ }^{13} \mathrm{C}$ and ${ }^{1} \mathrm{H}$ NMR ( $\delta$ in ppm) of $\mathbf{1 - 5}$ in $\mathrm{D}_{2} \mathrm{O}$

\begin{tabular}{lllllllll}
\hline Compound & C1 & C2 & C3a & C4 & C5 & H1 & H4 & H5 \\
& & & C7a & C7 & C6 & & H7 & H6 \\
\hline $\mathbf{1}^{\mathbf{a}}$ & 34.5 & 143.51 & 131.0 & 114.5 & 127.4 & 4.84 & 7.81 & 7.60 \\
$\mathbf{2}$ & 34.4 & 143.7 & 131.4 & 114.6 & 127.2 & 4.81 & $7.82(\mathrm{~m})$ & $7.62(\mathrm{~m})$ \\
$\mathbf{3}$ & 36.3 & & 136.5 & 115.2 & 124.3 & 4.48 & $7.39(\mathrm{~m})$ & $7.67(\mathrm{~m})$ \\
$\mathbf{4}$ & 36.3 & & & $115.0(\mathrm{~b})$ & 123.7 & 4.28 & $7.36(\mathrm{~m})$ & $7.67(\mathrm{~s}, \mathrm{~b})$ \\
$\mathbf{5}$ & 36.6 & & & $115.6(\mathrm{~b})$ & 123.7 & 4.27 & $7.27(\mathrm{~s}, \mathrm{~b})$ & $7.50(\mathrm{~b})$ \\
\hline
\end{tabular}

${ }^{\mathrm{a}}$ Reference 11 


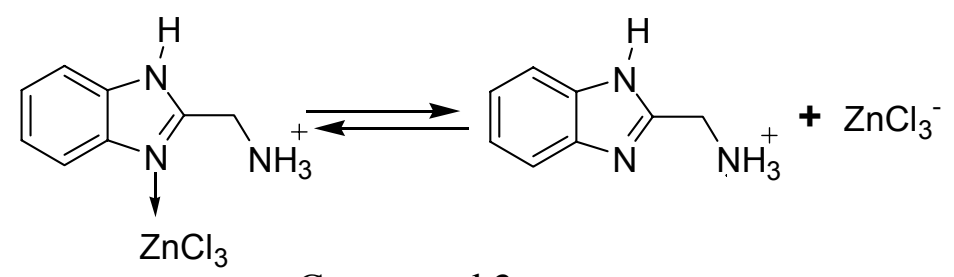

Compound 3

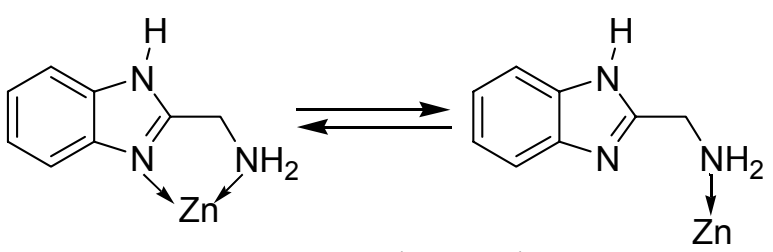

Compounds 4 and 5

Scheme 2. $\mathrm{N} \rightarrow \mathrm{Zn}$ bond-breaking equilibrium in $\left[\mathrm{H}_{2} \mathrm{LZnCl}_{3}\right] \cdot \mathrm{H}_{2} \mathrm{O}$ 3, $\left[\mathrm{HLZnCl}_{2}\right] \mathbf{4}$ and $\left[(\mathrm{HL})_{2} \mathrm{ZnCl}\right] \mathrm{Cl} \cdot \mathrm{H}_{2} \mathrm{O} 5$ compounds.

\section{X-Ray crystallography}

The X-ray crystallography corroborates the molecular structure of 2-5 (Table 2) and shows the presence of strong intermolecular hydrogen bonds. Molecule $\mathbf{2}$ is not a coordination compound because all the coordinated centers in the $1 \mathrm{H}$-benzimidazol-2-ylmethanamine are blocked by N$\mathrm{H}$ bonds. However, the $\mathrm{ZnCl}_{4}{ }^{2-}$ anion takes part in the hydrogen bond network. It is interesting that only three $\mathrm{Cl}$ atoms in $\mathrm{ZnCl}_{4}{ }^{2-}$ anion are acceptors of $\mathrm{H}$ atoms (Figure 2) and this fact is reflected in the $\mathrm{Zn}-\mathrm{Cl}$ bond length. Thus, $\mathrm{Zn1-Cl1}$ and $\mathrm{Zn1-Cl2}$ statistically have (e.s.d.) the same bond lengths [2.317(1) and 2.297(1) $\AA$ respectively] and these are longer than $\mathrm{Zn} 1-\mathrm{Cl} 3$ $[2.258(1) \AA]$. These differences can be attributed to $\mathrm{Cl} 1$ and $\mathrm{Cl} 2$ having stronger intermolecular hydrogen bonds with N2-H2B and N1-H1 than the one $\mathrm{Cl} 3$ has with N3-H3. Finally, Cl4 does not act as acceptor of hydrogen atoms and the bond length $\mathrm{Zn} 1-\mathrm{Cl} 4$ is the shortest [2.233(1) $\AA$ ]. The $\mathrm{H}$ atoms are donated by ammonia and imidazole groups, and in the hydrogen bond pattern, three graph sets with pseudo-macrocyclic structure can be distinguished: $\mathbf{R}_{4}^{4}(\mathbf{1 8})$ involving

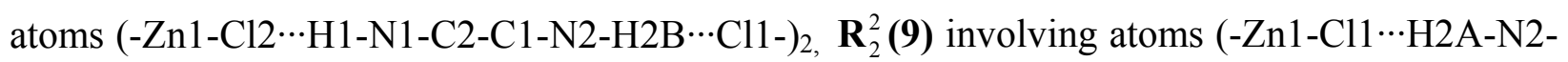
C1-C2-N3-H3 $\cdots \mathrm{Cl} 3-)$, and $\mathbf{R}_{4}^{2}(\mathbf{8})$ involving atoms $(\mathrm{Cl1} \cdots \mathrm{H} 2 \mathrm{~B}-\mathrm{N} 2-\mathrm{H} 2 \mathrm{~A} \cdots \mathrm{C} 11-)_{2} \cdot{ }^{35}$ 
Table 2. Crystal data of 2-5

\begin{tabular}{|c|c|c|c|c|}
\hline & 2 & 3 & 4 & 5 \\
\hline Formula & $\mathrm{C}_{8} \mathrm{H}_{11} \mathrm{Cl}_{4} \mathrm{~N}_{3} \mathrm{Zn}$ & $\mathrm{C}_{16} \mathrm{H}_{22} \mathrm{Cl}_{6} \mathrm{~N}_{6} \mathrm{OZn}_{2}$ & $\mathrm{C}_{8} \mathrm{H}_{9} \mathrm{Cl}_{2} \mathrm{~N}_{3} \mathrm{Zn}$ & $\begin{array}{l}\mathrm{C}_{16} \mathrm{H}_{20} \mathrm{Cl}_{2} \mathrm{~N}_{6} \mathrm{O} \\
\mathrm{Zn}\end{array}$ \\
\hline $\mathrm{Fw}$ & 356.37 & 657.84 & 283.45 & 448.65 \\
\hline Space group & $\mathrm{P} 2(1) / \mathrm{c}$ & $\begin{array}{l}\mathrm{P} 2(1) / \mathrm{n} \\
\text { ell parameters }\end{array}$ & $\mathrm{P} 2(1) / \mathrm{n}$ & $\mathrm{P} 2(1) / \mathrm{n}$ \\
\hline $\mathrm{a}(\AA)$ & $15.516(3)$ & $14.205(3)$ & $7.670(2)$ & $9.719(2)$ \\
\hline $\mathrm{b}(\AA)$ & $9.441(2)$ & $7.422(2)$ & 14.931(3) & $10.685(2)$ \\
\hline c $(\AA)$ & $9.662(2)$ & $24.538(5)$ & $9.519(2)$ & 18.193(4) \\
\hline$\alpha\left(^{\circ}\right)$ & 90 & 90 & 90 & 90 \\
\hline$\beta\left(^{\circ}\right)$ & 107.19(3) & 104.99(3) & $91.05(3)$ & $102.17(3)$ \\
\hline$\gamma\left({ }^{\circ}\right)$ & 90 & 90 & 90 & 90 \\
\hline$V\left(\AA^{3}\right)$ & $1352.2(5)$ & 2499.3(9) & $1089.9(4)$ & $1847.0(6)$ \\
\hline $\mathrm{Z}$ & 4 & 4 & 4 & 4 \\
\hline$\mu\left(\mathrm{mm}^{-1}\right)$ & 2.582 & 2.582 & 2.706 & 1.638 \\
\hline$\rho_{\text {calcd }}\left(\mathrm{g} \mathrm{cm}^{-3}\right)$ & 1.751 & 1.748 & 1.727 & 1.613 \\
\hline \multicolumn{5}{|c|}{ Data Collection } \\
\hline$\theta$ limits $\left(^{\circ}\right)$ & $1.37<\theta<25.50$ & $1.51<\theta<25.00$ & $2.54<\theta<25.00$ & $2.21<\theta<25.00$ \\
\hline hkl limits & $\begin{array}{l}-16, \quad 16 ;-10 \\
10 ;-10,9\end{array}$ & $\begin{array}{l}-16,16 ;-8,8 ;-29, \\
24\end{array}$ & $\begin{array}{l}-9,9 ;-17,17 \\
-10,11\end{array}$ & $\begin{array}{l}-9,11 ;-12,12: \\
-21,21\end{array}$ \\
\hline no. Collected refl. & 6360 & 14622 & 6548 & 11064 \\
\hline $\begin{array}{l}\text { no. of Indep reflns } \\
\left(\mathrm{R}_{\mathrm{int}}\right)\end{array}$ & 1770 & $4399(0.0507)$ & $1919(0.0282)$ & $3254(0.0234)$ \\
\hline No. of obsed reflns & 1770 & $\begin{array}{l}4399 \\
\text { Refinement }\end{array}$ & 1919 & 3254 \\
\hline $\mathrm{R}$ & 0.0271 & 0.0398 & 0.0273 & 0.0267 \\
\hline $\mathrm{R}_{\mathrm{w}}$ & 0.0757 & 0.0964 & 0.0689 & 0.0702 \\
\hline No. of params & 154 & 298 & 163 & 315 \\
\hline Goodness-of-fit on $\mathrm{F}^{2}$ & 1.167 & 1.079 & 1.048 & 1.086 \\
\hline$\Delta \rho_{\min }\left(\mathrm{e} \AA^{-3}\right)$ & -0.328 & -0.403 & -0.225 & -0.387 \\
\hline$\Delta \rho_{\max }\left(\mathrm{e} \AA^{-3}\right)$ & 0.327 & 0.685 & 0.335 & 0.370 \\
\hline
\end{tabular}




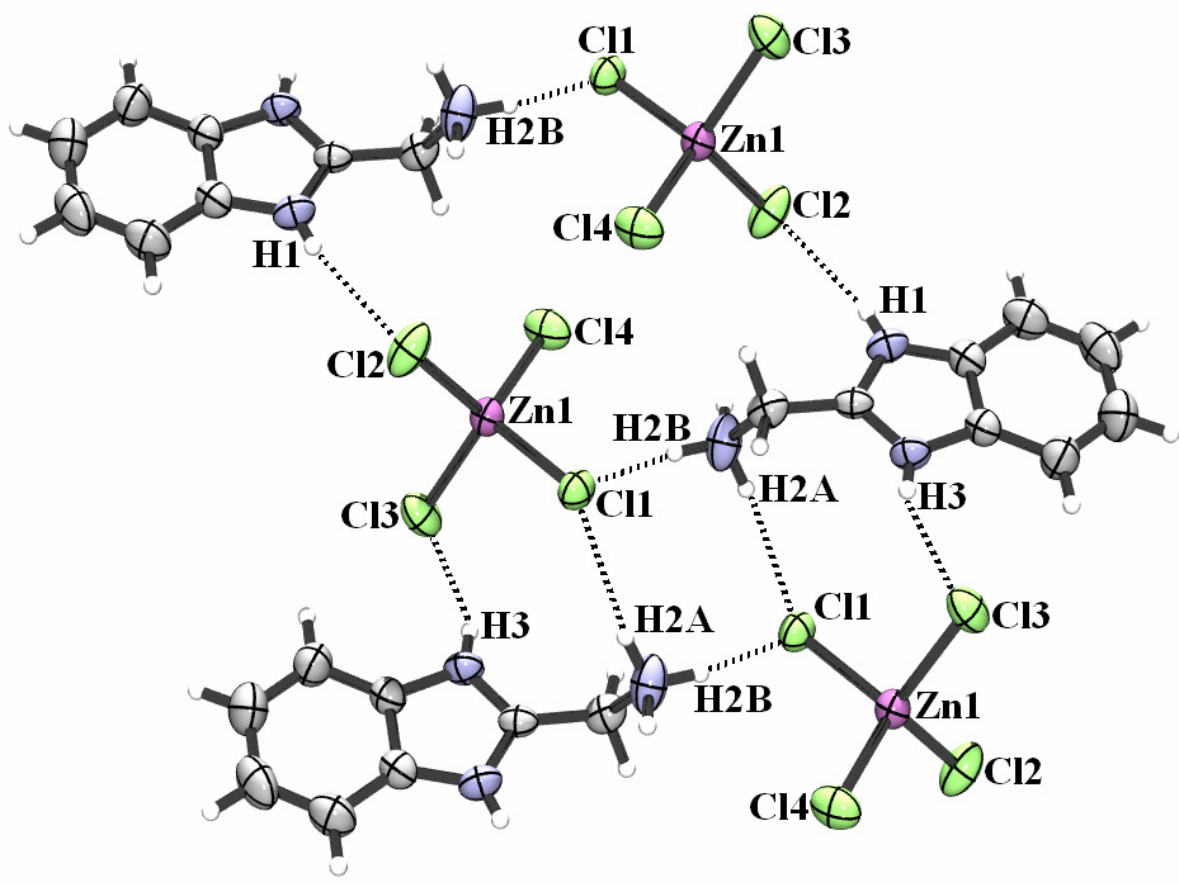

Figure 2. Crystal structure of $\left[\mathrm{H}_{3} \mathrm{LZnCl}_{4}\right] \mathbf{2}$ showing the hydrogen bond patterns: $\mathbf{R}_{4}^{4}(\mathbf{1 8})$, $\mathbf{R}_{2}^{2}(\mathbf{9})$ and $\mathbf{R}_{4}^{2}(\mathbf{8})$.

Compound $\mathbf{3}$ is mono-coordinated, the metal atom is bonded to an imidazolic nitrogen atom. In the unit cell there are two $\mathrm{Zn}$ complexes that are not symmetrically equivalent (Figure 3). Furthermore, 3a and $\mathbf{3 b}$ have different geometry parameters because they have different intermolecular interactions. Whereas, the imidazole hydrogen $\mathrm{H} 1$ of $\mathbf{3 a}$ has a strong intermolecular hydrogen bond with a water molecule $[\mathrm{N} 1 \cdots \mathrm{O} 1=2.779(7), \AA]$, the imidazole hydrogen $\mathrm{H} 1$ ' of $\mathbf{3 b}$ has a weak hydrogen bond with $\mathrm{Cl} 2$ [N1' $\cdots \mathrm{Cl} 2=3.285(10) \AA]$. The strong interaction of $\mathrm{H} 1$ with $\mathrm{O} 1$ is reflected in the bond length of $\mathrm{C} 2-\mathrm{N} 1$ [1.357(6) $\AA$ ] that is statistically larger than C2'-N1' [1.3261(6) $\AA$ ]. All $\mathrm{Cl}$ atoms in $\mathbf{3 a}$ and $\mathbf{3 b}$ are acceptors of $\mathrm{H}$ atoms (Figure 3), but they present different intermolecular interactions and the bond lengths $\mathrm{Zn}$ $\mathrm{Cl}$ are not the same. Four graph sets with pseudo-macrocyclic structure can be distinguished: The hydrogen bond of $\mathrm{Cl1}$ with $\mathrm{H} 2 \mathrm{C}^{\prime}\left[\mathrm{Cl1} \cdots \mathrm{N} 2{ }^{\prime}=3.304(5) \AA\right]$ and $\mathrm{Cl} 2$ with $\mathrm{H} 1{ }^{\prime}$ [Cl2 $\cdots \mathrm{N} 1{ }^{\prime}=$

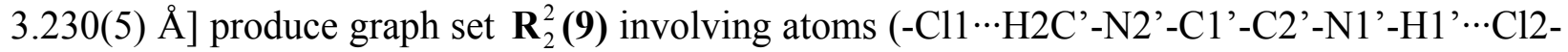

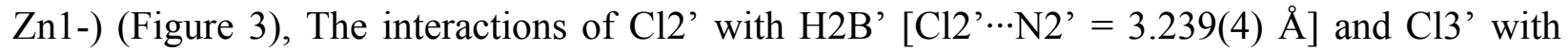
$\mathrm{H}_{2} \mathrm{~A}^{\prime}\left[\mathrm{Cl} 3^{\prime} \cdot \cdots \mathrm{N} 2\right.$ ' $\left.=3.215(5) \AA\right]$ cause the graph set $\mathbf{R}_{2}^{2}(\mathbf{6})$ involving atoms $\left(-\mathrm{Zn} 1^{\prime}-\mathrm{Cl} 2^{\prime} \cdot \cdots \mathrm{H} 4 \mathrm{~B}\right.$ '$\mathrm{N} 2$ '-H2A'…Cl3'-). Likewise, these interactions produce the graph set $\mathbf{R}_{2}^{2}(\mathbf{1 4})$ involving two possible set of atoms ( $\cdots \mathrm{H} 2 \mathrm{~A}^{\prime}-\mathrm{N} 2$ '-C1'-C2'-N3'-Zn1'-Cl3' $\left.\cdots\right)_{2}$ or ( $\cdots \mathrm{H} 2 \mathrm{~B}$ '-N2'-C1'-C2'-N3'$\left.\mathrm{Zn} 1{ }^{\prime}-\mathrm{Cl} 2^{\prime} \cdot \cdots\right)_{2}$. Finally, the Hydrogen bonds $\mathrm{Cl1} \cdots \mathrm{H} 2 \mathrm{C}^{\prime}-\mathrm{N} 2$ ' and $\mathrm{Cl}{ }^{\prime} \cdot \cdots \mathrm{H} 2 \mathrm{~A}^{\prime}-\mathrm{N} 2$ ' with the interaction $\mathrm{C} 11^{\prime} \cdots \mathrm{H} 2 \mathrm{~A}-\mathrm{N} 2[\mathrm{Cl} 5 \cdots \mathrm{N} 1=3.285(5) \AA]$ lead to a pseudo-macrocyclic estructure with a graph set $\mathbf{R}_{10}^{3}$ (70) involving (-Cl3' '..H2A'-N2'-C1' -C2'-N3'-Zn1'-C11' $\cdots$ H2A-N2-C1-C2-N3- 


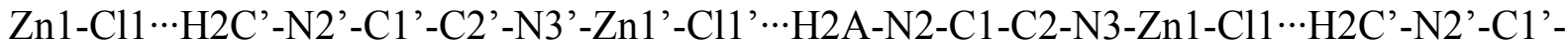
$\left.\mathrm{C} 2{ }^{\prime}-\mathrm{N} 3{ }^{\prime}-\mathrm{Zn} 1{ }^{\prime}-\right)_{2}$.

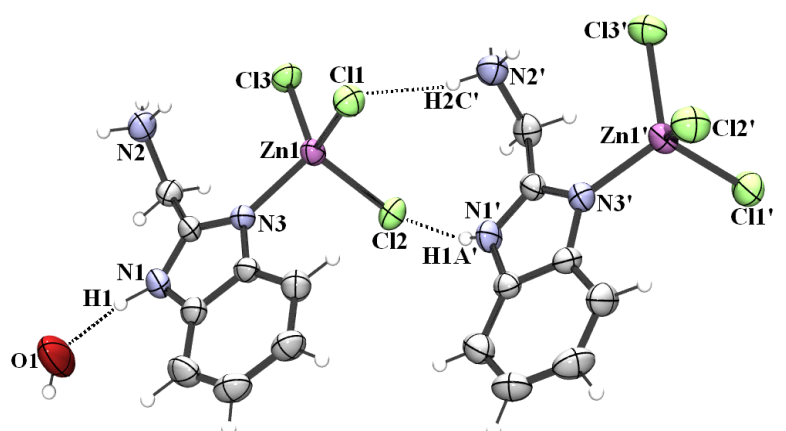

A

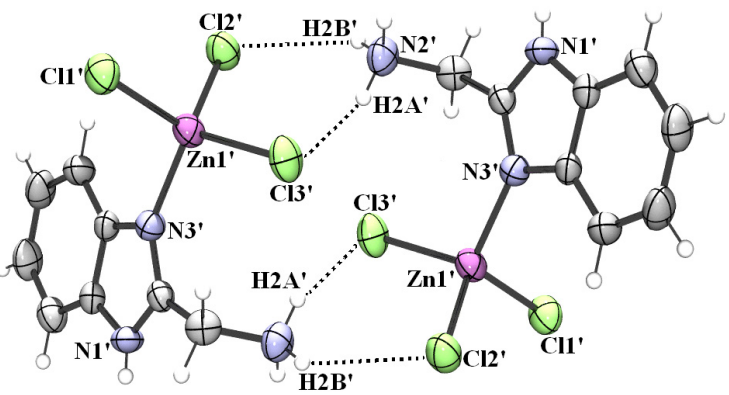

B

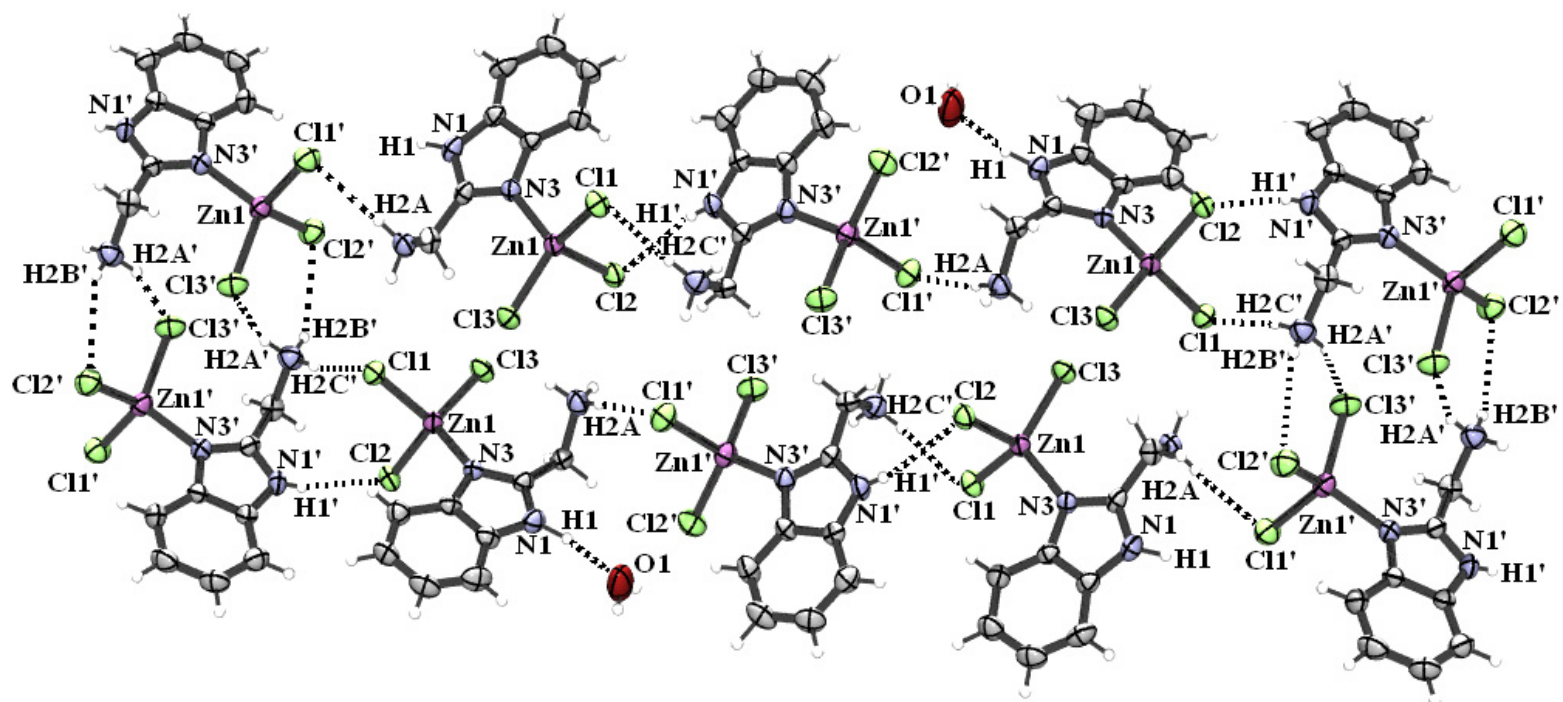

C

Figure 3. Crystal structure of $\left[\mathrm{H}_{2} \mathrm{LZnCl}_{3}\right] \cdot \mathrm{H}_{2} \mathrm{O} 3$ showing the hydrogen bond patterns: A) $\left.\mathbf{R}_{2}^{2}(\mathbf{9}), \mathrm{B}\right) \mathbf{R}_{2}^{2}(\mathbf{6})$ and $\mathbf{R}_{2}^{2}(\mathbf{1 4})$, C) $\mathbf{R}_{10}^{3}(\mathbf{7 0})$.

In compound 4 the benzimidazole ligand is coordinated to $\mathrm{Zn}$ in chelate form. The $\mathrm{Zn}$ atom has a deformed tetrahedral geometry where the bond length Zn1-C11 [2.240(1) A] is statistically longer than Zn1-Cl2 [2.235(1) $\AA$ ] (Figure 4). This fact is due to Cl1 having two intermolecular hydrogen bonds with $\mathrm{H} 1$ and $\mathrm{H} 22[\mathrm{Cl1} \cdots \mathrm{N} 3=3.410(3)$ and $\mathrm{Cl1} \cdots \mathrm{N} 2=3.501(3) \AA$ respectively] while $\mathrm{Cl} 2$ only presents one hydrogen bond with $\mathrm{H} 21[\mathrm{Cl} 2 \cdots \mathrm{N} 2=3.306(4) \AA]$. Four graph sets with pseudo-macrocyclic structure can be distinguished: $\mathbf{R}_{4}^{2}(\mathbf{1 4})$ involving atoms $(\cdots \mathrm{Cl1} \cdots \mathrm{H} 1$ $\mathrm{N} 1-\mathrm{C} 2-\mathrm{C} 1-\mathrm{N} 2-\mathrm{H} 22 \cdots)_{2}$ and $\mathbf{R}_{4}^{4}(\mathbf{1 8})$ involving atoms $(-\mathrm{H} 1 \cdots \mathrm{Cl} 1-\mathrm{Zn} 1-\mathrm{Cl} 2 \cdots \mathrm{H} 21-\mathrm{N} 2-\mathrm{C} 1-\mathrm{C} 2-\mathrm{N} 1-)_{2}$. 


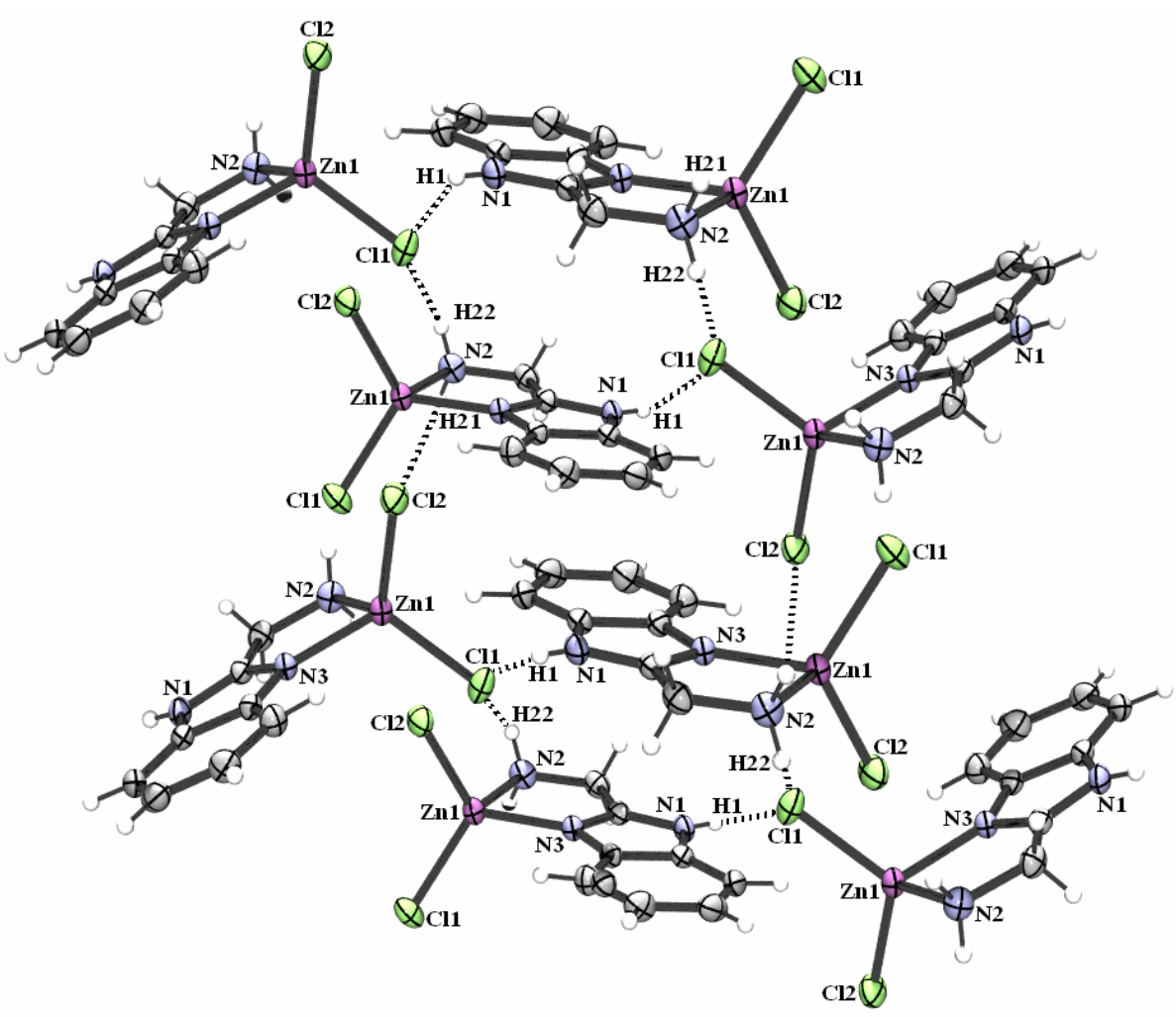

Figure 4. Crystal structure of $\left[\mathrm{HLZnCl}_{2}\right] \mathbf{4}$ showing the hydrogen bond patterns: $\mathbf{R}_{4}^{2}(\mathbf{1 4})$ and $\mathbf{R}_{4}^{4}$ (18).

In compound 5 two $1 H$-benzimidazol-2-ylmethanamine ligands are coordinated to $\mathrm{Zn}$ atom in chelate form (Figure 5). The $\mathrm{Zn}$ atom has a deformed trigonal bipyramidal geometry where the chlorine $\mathrm{C} 11$ and amine nitrogen (N2 and N2') atoms are disposed in equatorial positions. The imidazole nitrogen atoms (N3 and N3') are located in apical positions and statistically have the same bond lengths [Zn1-N3 = 2.113(2) $\AA$ ] and [Zn1-N3' = 2.111(2) $\AA$ ]. However, the Zn1-N2' bond length [2.200(2) $\AA]$ is statistically bigger than Zn1-N2 [2.114(2) $\AA]$ and therefore, the N2'Zn1-N3' bond angle $\left[77.25(7)^{\circ}\right]$ is shorter than N2-Zn1-N3 [80.41(7) $]$. Thus, in compound 5 the two HL are not equivalently coordinated to $\mathrm{Zn}$. This fact is reflected in the supramolecular arrangement that 5 adopt (Figure 5). For example, the two hydrogen atoms bonded to N2 have a intermolecular hydrogen bond with $\mathrm{Cl} 2[\mathrm{~N} 2 \cdots \mathrm{Cl} 2=3.393(2) \AA$ for $\mathrm{H} 2 \mathrm{~A}$ and 3.474(2) $\AA$ for $\mathrm{H} 2 \mathrm{~B}$ ] and, only one hydrogen atom (H2B') bonded to N2' presents hydrogen interactions $\left[\mathrm{N} 2{ }^{\prime} \cdot{ }^{\prime} \mathrm{Cl} 2=3.489(3) \AA\right]$. Moreover, the imidazole hydrogen atoms $\mathrm{H} 1$ and $\mathrm{H} 1$ ' have different interactions: whereas $\mathrm{H} 1$ atom interacts with $\mathrm{O} 1[\mathrm{~N} 1 \cdots \mathrm{O} 1=2.908(3) \AA]$, H1' presents an intermolecular interaction with $\mathrm{Cl1}\left[\mathrm{N1}{ }^{\prime} \cdots \mathrm{Cl1}=3.337(2) \AA\right]$. The presence of the $\mathrm{Cl} 2$ anion and water molecules is important because they take part in of the hydrogen bond network and likely stabilize the crystalline structure. Three graph sets with pseudo-cyclic structure can be distinguished: $\quad \mathbf{R}_{\mathbf{2}}^{1}(\mathbf{6})$ motif involving (-Zn1-N2'-H2B' $\left.\cdots \mathrm{Cl} 2 \cdots \mathrm{H} 2 \mathrm{~B}-\mathrm{N} 2-\right), \quad \mathbf{R}_{5}^{4}(\mathbf{1 8})$ motif 
involving (-N2-H2B $\cdots \mathrm{C} 12 \cdots \mathrm{H} 1 \mathrm{~F}-\mathrm{O} 1 \cdots \mathrm{H} 1-\mathrm{N} 1-\mathrm{C} 2-\mathrm{C} 1-)_{2}$, and $\mathbf{R}_{4}^{4}(\mathbf{1 6})$ motif involving ( $\cdots \mathrm{H} 1-\mathrm{N} 1-$

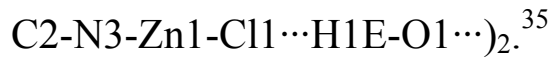

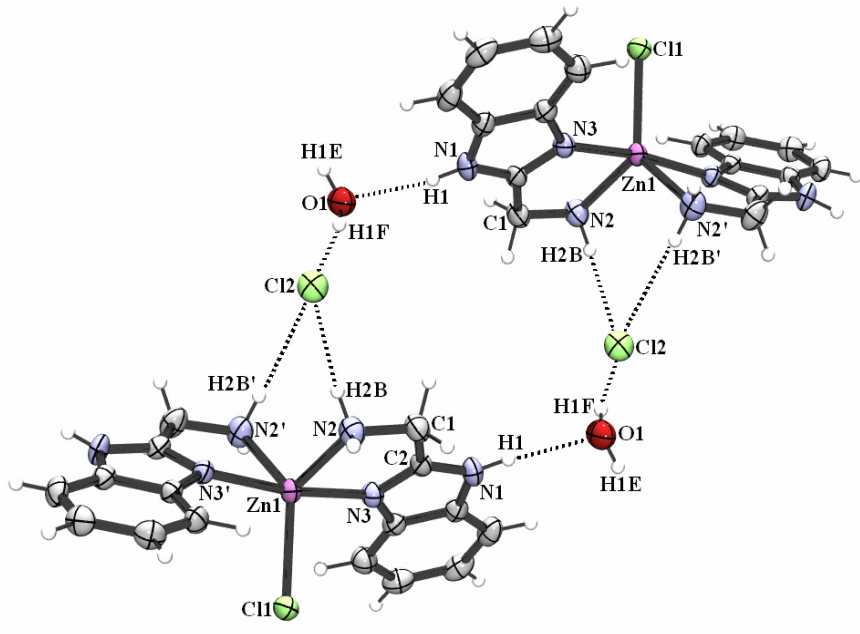

A

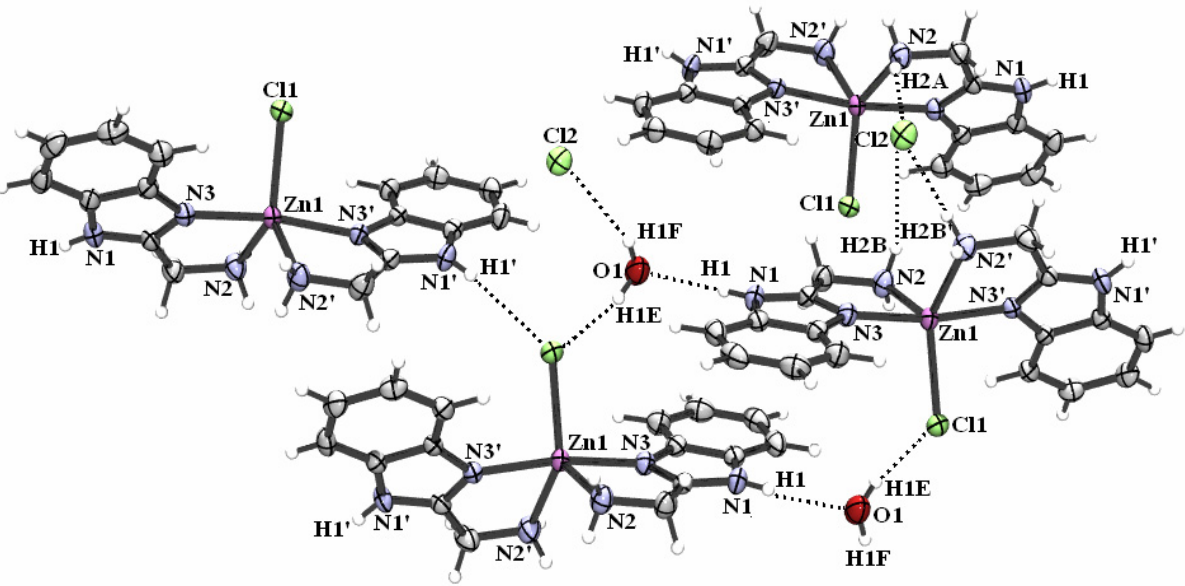

B

Figure 5. Crystal structure of $\left[(\mathrm{HL})_{2} \mathrm{ZnCl}\right] \mathrm{Cl} \cdot \mathrm{H}_{2} \mathrm{O} 5$ showing the hydrogen bond patterns: A) $\mathbf{R}_{\mathbf{2}}^{1}(\mathbf{6})$ and $\mathbf{R}_{5}^{4}(\mathbf{1 8})$, B) $\mathbf{R}_{4}^{4}(\mathbf{1 6})$.

In conclusion, the synthesis of compounds 2-5 has strong dependence on $\mathrm{pH}$ and concentration of the reactants. The coordination modes of $\mathrm{Zn}(\mathrm{II})$ with $1 H$-benzimidazol-2ylmethanamine depend on the acid-base behavior of the ligand and the existence of the metallic ion in solution. The X-ray crystallography of 2-5 shows the presence of strong hydrogen bonds that produce pseudo-macrocyclic networks. The presence of the chloride ion in the crystalline structures is important since it maximizes the hydrogen bond interactions. The NMR studies suggest that compounds 3-5 have fluxional behavior in aqueous solution, where the $\mathrm{N} \rightarrow \mathrm{Zn}$ bonds present breaking phenomena. 


\section{Experimental Section}

General Procedures. Water was freshly distilled and de-ionized before use. Melting points were measured on a Mel-Temp II apparatus and are uncorrected. The IR spectra and Raman were recorded on a Perkin-Elmer System Spectrum GX spectrophotometer. Mass spectra were recorded on JEOL MStation JMS-700 with FAB method and 3-nitrobenzyl alcohol (NBA) as matrix. Elemental analyses were determined on a Perkin-Elmer Series II CHNS/O analyzer 2400 instrument. NMR spectra were obtained on a JEOL GXS-400 MHz spectrometer in $\mathrm{D}_{2} \mathrm{O}$ solution. Chemical shifts (ppm) are relative to $\mathrm{MeOH}$ as external reference for ${ }^{1} \mathrm{H}$ and ${ }^{13} \mathrm{C} . \mathrm{pH}$ measurements were obtained using a Radiometer-Copenhagen PHM $250 \mathrm{pH}$-meter equipped with an ORION combined ROSS pH-electrode. Calibration of the electrode system was performed with Radiometer-Copenhagen IUPAC standard buffers of $\mathrm{pH} 4.005,7.000$ and 10.012 .

Data was collected on a Bruker Smart 6000 diffractometer equipped with a CCD area detector $\left(\lambda_{\text {Mok } \alpha}=0.71073 \AA\right.$, monochromar: graphite $)$. Frames were collected via $\omega / \phi$-rotation $(\Delta / \omega=$ $0.3^{\circ}$ ) at $10 \mathrm{~s}$ per frame (program SMART). ${ }^{36}$ The measured intensities were reduced to $\mathrm{F}^{2}$ without absorption correction (program SAINT-NT ${ }^{37}$ ). Structure solution, refinement and data output were carried out with the SHELXTL-NT program package. ${ }^{38}$ The non-hydrogen atoms were refined anisotropically. All $\mathrm{H}$ atoms in compounds $\mathbf{4}$ and $\mathbf{5}$ were located in a difference Fourier map and refined isotropically. In compounds $\mathbf{2}$ (except H1, H3) and $\mathbf{3}$ (except H1, H16, $\mathrm{H} 17, \mathrm{H1}$ '), the $\mathrm{H}$ atoms were placed in geometrically calculated positions using a riding model. Although we examined the yield of compounds 2-5 varying concentration of the reagents or $\mathrm{pH}$, we only show the best experimental procedure that we found for each $\mathrm{Zn}(\mathrm{II})$ compound.

\section{(1H-Benzimidazol-2-ylmethanamine)tetrachlorozincate(2-) dihydrogen (2)}

A mixture of $0.0261 \mathrm{~g}(0.4 \mathrm{mmol})$ of $\mathrm{Zn}$ and $100 \mu \mathrm{L}$ of concentrated $\mathrm{HCl}$ was diluted up to $2 \mathrm{~mL}$ with de-ionized water. Then, $2 \mathrm{~mL}$ of a $0.2 \mathrm{M}$ solution $(0.4 \mathrm{mmol})$ of $1 H$-benzimidazol-2ylmethanamine hydrate 1 were added. The mixture was stirred at room temperature for 5 minutes. Slow evaporation of the solvent yielded $0.0796 \mathrm{~g}(56 \%)$ of 2 as colorless crystals. Mp 293-295 ${ }^{\circ} \mathrm{C}$. Found: $\mathrm{C}, 26.9 ; \mathrm{H}, 3.1 ; \mathrm{N}, 11.1 ; \mathrm{C}_{8} \mathrm{H}_{11} \mathrm{~N}_{3} \mathrm{Cl}_{4} \mathrm{Zn} \bullet 0.4 \mathrm{H}_{2} \mathrm{O}$ requires $\mathrm{C}, 26.4, \mathrm{H}, 3.3, \mathrm{~N}$, 11.6. $\mathrm{m} / \mathrm{z}(\mathrm{FAB}, 10 \mathrm{eV}, \mathrm{NBA})$ no $\left(\mathrm{M}^{+}\right), 281\left(\mathrm{M}^{+}-2 \mathrm{HCl}\right)$.

\section{(1H-benzimidazol-2-ylmethanamine- $\left.\mathrm{k} \mathrm{N}^{3}\right)$ trichlorozincate(1-) hydrogen hydrate (3)}

A mixture of $0.0261 \mathrm{~g}(0.4 \mathrm{mmol})$ of $\mathrm{Zn}$ and $78.7 \mu \mathrm{L}$ of concentrated $\mathrm{HCl}$ was diluted up to 2 $\mathrm{mL}$ with de-ionized water. Then, $2 \mathrm{~mL}$ of a $0.2 \mathrm{~N}$ solution $(0.4 \mathrm{mmol})$ of $1 H$-benzimidazol-2ylmethanamine dihydrochloride hydrate $\mathbf{1}$ were added. The $\mathrm{pH}$ was adjusted to 3.5 with $\mathrm{NaOH} 1$ $\mathrm{M}$ and the mixture was stirred at room temperature for 5 minutes. Slow evaporation of the solvent yielded $0.0665 \mathrm{~g} \mathrm{(51 \% )} \mathrm{of} \mathbf{3}$ as orange crystals. Mp 269-271 ${ }^{\circ} \mathrm{C}$. Found: $\mathrm{C}, 26.9 ; \mathrm{H}, 3.3$; $\mathrm{N}, 11.3 ; \mathrm{C}_{8} \mathrm{H}_{10} \mathrm{~N}_{3} \mathrm{Cl}_{3} \mathrm{Zn} \cdot 2.1 \mathrm{H}_{2} \mathrm{O}$ requires $\mathrm{C}, 26.9, \mathrm{H}, 4.0, \mathrm{~N}, 11.8 . \mathrm{m} / \mathrm{z}(\mathrm{FAB}, 10 \mathrm{eV}, \mathrm{NBA})$ no $\left(\mathrm{M}^{+}\right), 289\left(\mathrm{M}^{+}-\mathrm{C}_{2} \mathrm{H}_{4} \mathrm{Cl}\right)$. 


\section{(1H-Benzimidazol-2-ylmethanamine- $\left.\kappa^{2} \mathrm{~N}^{2}, \mathrm{~N}^{3}\right)$ dichlorozinc(II) (4)}

A mixture of $0.1321 \mathrm{~g}(0.6 \mathrm{mmol})$ of $1 \mathrm{H}$-benzimidazol-2-ylmethanamine dihydrochloride hydrate 1 diluted in $5 \mathrm{~mL}$ of de-ionized water and $0.3293 \mathrm{~g}(0.6 \mathrm{mmol})$ of $3 \mathrm{Zn}(\mathrm{OH})_{2} \cdot 2 \mathrm{ZnCO}_{3}$ was stirred at room temperature for 24 hours. Then, the resulting mixture was filtered and slow evaporation of dissolvent yielded $0.0122 \mathrm{~g}(7 \%)$ of 4 as orange crystals. Mp 249-251 ${ }^{\circ} \mathrm{C}$. Found: C, 33.9; $\mathrm{H}, 3.2 ; \mathrm{N}, 14.1 ; \mathrm{C}_{8} \mathrm{H}_{9} \mathrm{~N}_{3} \mathrm{Cl}_{2} \mathrm{Zn}$ requires $\mathrm{C}, 33.9, \mathrm{H}, 3.2, \mathrm{~N}, 14.8 . \mathrm{m} / \mathrm{z}(\mathrm{FAB}, 10 \mathrm{eV}, \mathrm{NBA})$ no $\mathrm{M}^{+}, 279\left(\mathrm{M}^{+}-\mathrm{H}_{2}\right), 246\left(\mathrm{M}^{+}-\mathrm{Cl}\right)$.

\section{Bis[1H-Benzimidazol-2-ylmethanamine- $\left.\mathrm{k}^{2} \mathrm{~N}^{2}, \mathrm{~N}^{3}\right]$ chlorozinc(II) chloride hydrate (5).}

A mixture of $0.0880 \mathrm{~g}(0.4 \mathrm{mmol})$ of $1 \mathrm{H}$-benzimidazol-2-ylmethanamine dihydrochloride hydrate 1 diluted in $5 \mathrm{~mL}$ of de-ionized water and $0.2196 \mathrm{~g}(0.4 \mathrm{mmol})$ of $3 \mathrm{Zn}(\mathrm{OH})_{2} \cdot 2 \mathrm{ZnCO}_{3}$ was stirred at room temperature for 30 minutes. Then, the result mixture was filtered and slow evaporation of the solvent yielded $0.0362 \mathrm{~g}(23 \%)$ of 5 as amber crystals. Mp 210-212 ${ }^{\circ} \mathrm{C}$. Found: C, 41.9; $\mathrm{H}, 4.6 ; \mathrm{N}, 17.8 ; \mathrm{C}_{16} \mathrm{H}_{18} \mathrm{~N}_{6} \mathrm{Cl}_{2} \mathrm{Zn} \bullet 1.7 \mathrm{H}_{2} \mathrm{O}$ requires $\mathrm{C}, 41.7, \mathrm{H}, 4.7, \mathrm{~N}, 18.2 . \mathrm{m} / \mathrm{z}$ (FAB, $10 \mathrm{eV}, \mathrm{NBA}) 393\left(\mathrm{M}^{+}\right), 357\left(\mathrm{M}^{+}-\mathrm{HCl}\right), 246\left(\mathrm{M}^{+}-\mathrm{C}_{8} \mathrm{H}_{9} \mathrm{~N}_{3}\right)$.

\section{Supplementary Information Available}

Crystallographic data (excluding structure factors) have been deposited with the Cambridge Crystallographic Data Center as CCDD 651136, 651137, 651138 and 651139. Copies of the data can be obtained free of charge on application to: The Director, CCDC, 12 Union Road, Cambridge, CB2 IEZ, UK (fax: +44-1223-336-033; e-mail: deposit@ccdc.cam.ac.uk or www.ccdc.cam.ac.uk).

\section{Acknowledgements}

This work was supported by CONACYT-México (832240-E and J33279-E). AR T-B thanks Alejandro Álvarez for reading the manuscript and for his helpful comments.

\section{References}

1. Sarret, G.; Manceau, A.; Cuny, D.; Van Haluwyn, C.; Déruelle, S.; Hazemann, J.; Soldo, Y.; Eybert-Bérard, L.; Menthonnex, J. Environ. Sci. Technol. 1998, 32, 3325.

2. Cakmak, I. New Phytol. 2000, 146, 185.

3. Lin, Q.; Barbas, C. F.; Schultz, P. G. J. Am. Chem. Soc. 2003, 125, 612.

4. Pelmenschikov, V.; Blomberg, M. R. A.; Siegbahn, P. E. M. J. Biol. Inorg Chem. 2002, 7, 284. 
5. Simó, B.; Perelló, L.; Ortiz, R.; Castiñeiras, A.; Latorre, J.; Cantón, E. J. Inorg. Biochem. 2000, 81, 275.

6. Petros, A. K.; Reddi, A. R.; Kennedy, M. L.; Hyslop, A. G.; Gibney, B. R. Inorg. Chem. 2006, 45, 9941.

7. Hasegawa, K.; Ono, T.; Noguchi, T. J. Phys. Chem. A, 2002, 106, 3377.

8. Dalosto, S. D.; Calvo, R.; Pizarro, J. L.; Arriortua, M. I. J. Phys. Chem. A, 2001, 105, 1074.

9. Matthews, C. J.; Clegg, W.; Heath, S. L.; Martin, N. C.; Stuart, M. N.; Lockhart, J. C. Inorg. Chem. 1998, 37, 199.

10. Tlahuext, H.; Tlahuextl, M.; López-Gómez, S.; Tapia-Benavides, A. R. Acta Cryst. 2007, E63, 1263.

11. Sierra-Zenteno, A.; Galán-Vidal, C. A.; Tapia-Benavides, R. Rev. Soc. Quím. Méx. 2002, 46, 125.

12. García-Orozco, I.; Tapia-Benavides, A. R.; Alvarez-Toledano, C.; Toscano, R. A.; RamírezRosales, D.; Zamorano-Ulloa, R.; Reyes-Ortega, Y. J. Mol. Struct. 2002, 604, 57.

13. Quiroz-Castro, E.; Bernes, S.; Barba-Behrens, N.; Tapia-Benavides, R.; Contreras, R.; Nöth, H. Polyhedron 2000, 19, 1479.

14. Custelcean, R.; Haverlock, T. J.; Moyer, B. A. Inorg. Chem. 2006, 45, 6446.

15. Edlin, C. D.; Parker, D.; Perry, J. J. B.; Chartroux, C.; Gloe, K. New J. Chem. 1999, $23,819$.

16. Rojas-Hernández, A.; Ramírez, M. T.; González, I. Anal. Chim. Acta 1993, 278, 321.

17. Rojas, A.; González, I. Anal. Chim. Acta 1986, 187, 279.

18. Anderson, A. J.; Mayanovic, R. A.; Bajt, S. Can. Mineral. 1995, 33, 499.

19. Morsy, M. A.; Al-Khaldi, M. A.; Suwaiyan, A. J. Phys. Chem. A 2002, 106, 9196.

20. Podstawka, E.; Ozaki, Y.; Proniewics, L. M. Appl. Spectrosc. 2004, 58, 570.

21. Merker, U.; Srivastava, H. K.; Callegari, A.; Lehmann, K. K.; Scoles, G. Phys. Chem. Chem. Phys. 1999, 1, 2427.

22. Giannerini, T.; Tellez, C. A.; Hollauer, E. Quim. Nova 2004, 27, 206.

23. Temel, H.; Çakir, Ü.; Otludil, B.; Uğraş, O. B. Synth. React. Inorg. Me.-Org. Chem. 2001, $31,1323$.

24. Guevara-García, J. A.; Barba-Behrens, N.; Tapia-Benavides, A. R.; Rosales-Hoz, M. J.; Contreras, R. Inorg. Chim. Acta 1995, 239, 93.

25. Pafford, R. J.; Chou, J.; Rauchfuss, T. B. Inorg. Chem. 1999, 38, 3779.

26. Vahrenkamp, H. Acc. Chem. Res. 1999, 32, 589.

27. Wu, G.; Lavigne, J. A.; Tao, Y.; D’Iorio, M.; Wang, S. Inorg. Chem. 2000, 39, 5248.

28. Chen, J.; Willis, P. G.; Parkin, S.; Cammers, A. Eur. J. Org. Chem. 2005, 171.

29. Claramunt, R. M.; Santa-María, M. D.; Infantes, L.; Cano, F. H.; Elguero, J. J. Chem. Soc., Perkin Trans 2. 2002, 564.

30. Papadopoulos, E. P.; Hollstein, U. Org. Magn. Reson. 1982, 19, 188.

31. Claramunt, R. M.; López, C.; Santa-María, M. D.; Sanz, D.; Elguero, J. Prog. NMR Spectrosc. 2006, 49, 169.

32. Claramunt, R. M.; López, C.; Elguero, J. Arkivoc 2006, (v), 5. 
33. Claramunt, R. M.; López, C.; Alkorta, I.; Elguero, J.; Yang, R.; Schulman, S. Magn. Reson. Chem. 2004, 42, 712.

34. Saito, H.; Tanaka, Y.; Nagata, S. J. Am. Chem. Soc. 1973, 24, 324.

35. Bernstein, J.; Davis, R. E.; Shimoni, L.; Chang, N. Angew. Chem. Int. Ed. 1995, 34, 1555.

36. Bruker Analytical X-Ray Systems. SMART: Bruker Molecular Analysis Research Tool, V.5. 057 c, 1997-1998.

37. Bruker Analytical X-Ray Systems. SAINT + NT, Version 6.01, 1999.

38. Bruker Analytical X-Ray Systems. SHELXTL-NT, Version 5.10, 1999. 